\title{
PPP Z POHLEDU TEORIE VEŘEJNÉHO INVESTOVÁNÍ
}

\author{
Jan Ostřížek
}

\section{Klíčová slova:}

Public Private Partnership, veřejné výdaje, New Public Management, New public service

\section{Key words:}

Public Private Partnership, Public expenditures, New Public Management, New public service

\begin{abstract}
Abstrakt
Příspěvek se zabývá teoretickými východisky a koncepty, které poskytují základ pro využití formy financování a pořízení veřejné infrastruktury a služeb prostřednictvím partnerství veřejného a soukromého sektoru, tedy PPP (Public Private Partnership). Vhodnost projektů typu PPP je $v$ tomto příspěvku hodnocena především z pohledu organizace a řízení veřejné správy a ve vztahu $\mathrm{k}$ cílům a principům zvoleného př́stupu.
\end{abstract}

\begin{abstract}
The article deals with the theoretical background of the alternative way of financing, building and operating of public infrastructure and public services. The alternative way mentioned above is the Public Private Partnership concept. The eligibility of Public private partnership is evaluated through the theory of organisation and operation of the public administration.
\end{abstract}

\section{1 Úvod}

Projekty realizované prostřednictvím partnerství veřejného a soukromého sektoru jsou z hlediska ukotvení v ekonomické teorii a teorii veřejné správy v České republice poměrně novou problematikou, stejně tak jako je PPP novou alternativou pořízení, správy či financování veřejné infrastruktury a veřejných služeb. I přesto, že Politika vlády ČR v oblasti partnerství veřejného a soukromého sektoru byla formulována a schválena již v roce 2004 vládou České republiky, jsou realizované projekty PPP spíše výjimkou, a to především na úrovni projektů pilotních. Bohužel i v akademickém prostředí jsou PPP projekty mnohdy považovány za oblast novou a neprobádanou, a v oblasti teorie a vazby na teorie naprosto neznámou.

Cílem práce je proto vymezit teoretické základy pro využití alternativních forem financování, pořízení, př́ípadně správy veřejných služeb a veřejné infrastruktury a zhodnotit jejich přijatelnost $\mathrm{z}$ hlediska moderních trendů organizace a řízení ve veřejné správě. Hlavní pozornost je věnována konceptu veřejně-soukromých partnerství (PPP). I přesto, že se v rámci České republiky, a kontinentální Evropy obecně, jedná o relativně novou formu financování, lze nalézt teoretické koncepty a směry, které projekty typu PPP, i když ne zcela př́mo, podporují. Jedním z cílů této práce je tedy tyto přístupy nalézt a upozornit na ně.

Z důvodu teoretického uchopení příspěvku je převažující metodou modifikovaná textuální analýza, komparace teoretických přístupů a syntéza základních předpokladů zmíněných teorií se základními charakteristikami Public Private Partnership. Z výše uvedených důvodů bylo pracováno převážně se zahraniční teoretickou literaturou a dílčí výsledky a směřování 
výzkumu byly konzultovány s domácími i zahraničními experty v oboru veřejné správy a PPP. Příspěvek vychází z dlouhodobé publikační činnosti autora.

\section{PPP a teorie veřejného investování}

Charakteristika projektů PPP vyžaduje uvedení základních východisek pro veřejné investování. Veřejné investování či veřejné investice jsou takové investice, které jsou realizovány z veřejných zdrojů a jsou realizovány bud' přímo státem, nebo jím ovládanými entitami. Zároveň platí, že veřejné investice jsou nezbytným předpokladem hospodářského růstu a také možným kanálem řešení některých hospodářských problémů, jakými jsou např̀.

nezaměstnanost, zaostalost regionů, nedostatek soukromých investice apod. Řada autorů (Persky a Felsenstein, 2001; Bar-El, 2001 nebo WU, 1987) se shoduje na tom, že veřejné investice jsou jednou z možností, jak dosáhnout, při správné alokaci a načasování těchto investic, zásadních pokroků v oblasti regionálního rozvoje.

Přijmeme-li zjednodušení, že veřejné investice jsou totožné s velikostí výdajů veřejného sektoru, musíme zmínit existenci teoretického ukotvení vztahu veřejných výdajů a rozvinutosti ekonimiky, tedy Wagnerova zákona, který předpokládá rostoucí podíl veřejných výdajů na HDP v případě, kdy dochází k rozvoji industriální společnosti - růstu ekonomické úrovně státu. Platnost tohoto zákona $v$ dnešní době diskutabilní, což je dáno především dobou, kdy byl zákon formulován (konec 19. století) a tehdejším rozvojem veřejného sektoru v dynamicky se rozvíjející společnosti. I v současné době publikované studie zkoumající platnost Wagnerova zákona např̀. v České republice (Topinková, 2010) či v zemích EU (Karagianni et al., 2002) se shodují na tom, že prokázání platnosti Wagnerova zákona je problematické a závisí na zvoleném časovém období a využitých technikách testování. Odhlédneme-li od sociálních a podobných výdajů státních rozpočtů, a zaměříme-li se pouze na investiční výdaje, musíme platnost Wagnerova zákona pro dnešní rozvinuté ekonomiky také zpochybnit, nebot' investiční aktivita rozvinutých států (jejich vlád) se v posledních desetiletích, při současném ekonomickém růstu, spíše snižuje. Konkrétním prríkladem týkajícím se České republiky jsou stále se snižující objemy investic do dopravní infrastruktury v České republice. Tento trend potvrzuje ve své studii IMF (2004) a poukazuje na fakt, že takový vývoj může mít pro některé ekonomiky dlouhodobé negativní důsledky, přičemž jako příklad autoři uvádějí země Latinské Ameriky a jejich nedostatečnou infrastrukturní vybavenost, která je naprosto klíčová pro další ekonomický rozvoj. Navíc, pohlédneme-li na infrastrukturní investice optikou multiplikačních účinků, můžeme konstatovat, že právě tento typ investic má jeden z nejvyšších multiplikátorů vůbec. Pereé a Välilä (2008) tento trend potvrzují a dodávají, že v rámci Evropské unie přesto existují jisté výjimky.

Zmíněné výjimky se týkají tzv. kohezních regionů a regionů, jejichž rozvoj je významně saturován prostředky z fondů Evropské unie (strukturální fondy a fond soudržnosti), což jsou zpravidla regiony či přímo nové členské země, včetně České republiky. Ter-Minassian a Allen, autoři studie IMF (2004) uvádějí, že výše uvedený vývoj investic, resp. jejich nedostatek, je ve většině vyspělých států „dorovnáván“ investicemi soukromými, což, dle mého názoru, podporuje systematické využití projektů PPP, tedy zapojení soukromých zdrojů do veřejného investování. Pereé a Välilä (2008) se tuto tezi pokusili podpořit statistickými údaji, ovšem vzhledem k relativní mladosti politiky PPP se (vyjma Velké Británie, kde je politika PFI reálně uskutečňována od počátku devadesátých let minulého století) nemohli opřít o žádná signifikantní data. I přesto uvádějí, že právě ve zmíněné Velké Británii, Portugalsku a Řecku tvoří investice realizované prostřednictvím veřejně-soukromých 
partnerství 15-30 \% celkového objemu veřejných investic, což je dle mého názoru hodnota, ke které by měl podíl investiční hodnoty PPP projektů na celkových veřejných investicích tendovat. Využití těchto prostředků by umožnilo dramatickým zpo̊sobem zrychlit budování veřejné infrastruktury a pokrýt jejich neustále vzrůstající nedostatek. V České republice, vzhledem k faktu, že politika PPP byla vládou ČR schválena teprve v roce 2004 a dosud nebyl plně realizován žádný z robustních pilotních projektů, s obdobným podílem soukromých prostředků prozatím nemůžeme počítat. Výše zmíněný podíl PPP projektů na celkových investicích je dle názoru auora v České republice dosažitelný v horizontu 15-25 let, a to především v závislosti na politické vůli tyto projekty realizovat, ale také na souvisejícím, a do značené míry tento koncept determinujícím, legislativním prostředí.

V minulých letech bylo, a možno říci i v současné době je, obzvláště v České republice, financování, budování a správa veřejné infrastruktury doménou výhradně veřejného sektoru, potažmo státu - tedy součástí jeho hospodářské politiky. Počátkem osmdesátých let dvacátého století se ovšem ve Velké Británii a částečně i v USA část těchto aktivit přesunula i na soukromý sektor, což bylo důsledkem politiky Margaret Thatcherové a Ronalda Regana a jejich příklonu k privatizačním a dalším technikám. Ve zmíněné době se tudíž začíná výrazněji využívat koncept spolupráce veřejného a soukromého sektoru. Zapojení privátního sektoru do aktivit sektoru veřejného je možno diskutovat $\mathrm{z}$ mnoha pohledů. Pro účel této práce je ovšem rozhodující převážně otázka ekonomického př́istupu. Z hlediska ekonomické teorie se jedná o otázku stupně zapojení státu a jeho zásahů do ekonomiky. Vysoký stupeň zapojení státu, přičemž není nutné hovořit ihned o centrálně řízené ekonomice, s sebou pochopitelně nese zajištění infrastruktury ze strany veřejného sektoru, tzn. její státní vlastnictví. Protipólem tohoto chápání je stav, kdy je infrastruktura zajišt'ována z větší části soukromým sektorem. Otázkou zajišsění veřejné infrastruktury a služeb privátním sektorem se ovšem ekonomická teorie přímo podrobněji nezabývá. Dle názoru autora je pro PPP vhodným prostředím klasické pojetí laissez faire, kdy stát zajištuje pouze nejdůležitější funkce. Můžeme tedy nadneseně hovořit o minimálním státu, který zajišt'uje pouze základní veřejné statky a služby, jako jsou obrana, bezpečnost a justice. Ještě vhodnější podmínky z hlediska kvantity využití PPP vytváří přístup německých ordoliberálů (Ostř̌ǐžek, 2007), kteří kromě těchto základních funkcí státu zmíněných u laissez faire, vyžadují po státu vytvoření určitého řádu - v prrípadě PPP toto prostředí chápejme jako legislativní prostředí pro PPP a veřejné investování obecně. Holman (1999) uvádí, že ordoliberálové freiburské ekonomické školy si realizaci své teorie představovali tak, že stát vytvoří právně institucionální řád, který bude zárukou volné tržní konkurence a nezasahování státu do tržních procesů. To by ovšem znamenalo vystavení veřejných statků a služeb tržním tlakům, tedy interakci poptávky a nabídky, což by pradvěpodobně prodražilo využívání této infrastruktury pro koncového uživatele - pro občana. Důvodem zmíněného zdražení infrastruktury pro koncové uživatele by se pochopitelně stala nutnost navrácení investice realizované soukromým sektorem, jehož cílem je zisk, a to bez státních dotací či jiných forem dofinancování. Alternativním pojetím či doplněním tohoto přístupu může být např. Buchananův koncept klubových statků (Buchanan, 1965). Pohledem na PPP prizmatem vybraných ekonomických teorií se zabývá např́íklad Ostřížek a Kouba (2011).

I s ohledem na předchozí tvrzení a zmínění laissez faire jsme pochopitelně schopni identifikovat veřejné statky a služby, které by měly zůstat pod správou veřejného sektoru. V anglicky psané literatuře jsou tyto služby označovány jako „core government services“ a týkají se obrany, justice, ekonomické funkce státu (monetární, fiskální a kurzová politika) a vlastní vlády. Do těchto oblastí by soukromý sektor neměl mít možnost dle mého názoru příliš zasahovat, i když se může stát správcem podpůrných infrastruktur napomáhajících 
efektivnímu fungování těchto „core services“. Př́́kladem této spolupráce je soukromým sektorem spravovaná věznice (např. projekt věznice v Rapoticích), kdy soukromým sektorem je zajišt'ován její provoz (stravování, úklid, správa objektu), zatímco veřejných sektor zajišt’uje fungování vězeňské služby. Samotné „core services“ tedy klíčové funkce a aktivity vlády, by ovšem měly zůstat v působnosti veřejného sektoru.

Dalším znakem velkých infrastrukturálních projektů (nejedná se pouze o PPP projekty), který bezprostředně souvisí s ekonomickou teorií, je dle Ostř́ǐžka (2007) jejich výrazný sklon $\mathrm{k}$ monopolizaci. V rámci těchto projektů se ovšem nejedná o negativní deformaci trhu, nebot' důvody pro regionální monopolizaci některých projektů jsou velmi racionální, a jejich monopolizací se dosahuje vyšší efektivnosti poskytování veřejných služeb - viz existenci přirozeného monopolu. Podporu tohoto tvrzení nalezneme při demonstraci několika typových př́kladů, jimiž jsou dálnice, mosty nebo i méně investičně náročné čističky odpadních vod. Bylo by velmi neefektivní, aby ve stejném prostoru a čase existovaly dvě obdobné infrastruktury, tedy dvě dálnice vedle sebe, dva mosty vedle sebe či konkurenční osvětlení veřejných prostranství. Nejen, že by bylo pro konečného spotřebitele náročné stanovit si kritéria, dle kterých by vybral pro něj výhodnější variantu, ale, co je mnohem závažnějším problémem, který si dovolíme označit za celospolečenský, je značná neefektivita označitelná za přímé plýtvání s veřejnými, popř. soukromými zdroji. Nebezpečí, které se v monopolním postavení soukromého poskytovatele může skrývat, tkví v možnosti zneužití této dominance prostřednictvím neúměrného zvyšování požadovaných poplatků. Finanční podmínky a platební mechanismus jsou ovšem, zejména $v$ př́ípadě PPP, nedílnou a určující součástí smlouvy mezi soukromým a veřejným sektorem. Vhodné nastavení smluvních podmínek umožňuje omezení či úplnou eliminaci zmíněných negativ monopolní struktury.

\section{PPP a styl řízení veřejné správy}

Další pohled na zajištění infrastruktury existuje z pozice veřejné správy a její orientace na styl řízení. Pro náš účel, tedy zajištění infrastruktury soukromým sektorem samotným nebo ve spolupráci se sektorem veřejným, je nejpřijatelnější model řízení veřejné správy, který vznikl ke konci 70. let dvacátého století v anglosaských zemích. Tento směr je znám jako New public management (NPM), přičemž jeho český překlad se obvykle neuvádí. NPM je znám ve spojení stzv. „3E“. Tato 3E jsou reprezentována výrazy - economy (hospodárnost), efficiency (efektivnost), effectiveness (účinnost).

Nejen koncept NPM, ale i koncept ekonomického hodnocení PPP projektů, který je označován jako VFM (Value for Money - hodnota za peníze) je z teoretického hlediska těsně spjat se „společenskou efektivitou“ realizované investiční akce. Jakákoli investice, a především investice realizovaná $\mathrm{z}$ veřejných prostředků, popř. za účelem realizace veřejné infrastruktury či veřejné služby, by měla respektovat tyto ,3E“. Následující odstavce uvádějí základní charakteristiky výrazů - economy (hospodárnost), efficiency (efektivnost), effectiveness (účinnost).

Kritérium hospodárnosti (economy) vyjadřuje zisk odpovídajícího výstupu při co nejnižších nákladech (Glynn, 1985). Parker (1986) dodává, že kritérium hospodárnosti je splněno, je-li při nejnižších nákladech dosaženo pořízení či nabytí určitého statku v odpovídajícím množství a v odpovídající kvalitě. Poměrně svéráznou definici kritéria hospodárnosti uvádí Sheldon a McNamara (1991), kteří za hospodárné považují pořízení vhodného aktiva, ve vhodném množství, ve vhodném čase, na vhodném místě a při vhodných nákladech. Kritérium hospodárnosti je tím kritériem, které je státní správou obvykle nejvíce používáno při 
rozhodování o pořízení zamýšlené infrastruktury, nebot' velmi často bývá hlavním kritériem při posuzování nabídek na tuto realizaci nabídková cena. Faktem ovšem je, že samotná cena není při rozhodování vždy nejdůležitější, nebot' je třeba zohlednit i některé další kvantitativní a kvalitativní faktory, jakými jsou např. termín dodání daného aktiva, jeho kvalita apod. Konstrukce hodnotících kritérií je v případě dlouhodobých projektů typu PPP nezbytná a složitá, přičemž je třeba dbát na to, aby daná kritéria umožnila vybrat ekonomicky nejvýhodnější variantu (což může i nemusí být nabídka s nejnižší nabídkovou cenou) a nebyla kritérii omezujícími.

Kritérium efektivnosti (efficiency) je oproti předchozímu kritériu definováno odlišně. Podle Glynn (1985) se jedná o nalezení takového způsobu pořízení aktiva, kdy je při daných (disponibilních) nákladech pořízeno maximální množství aktiva. Alternativně se jedná o případ, kdy je při minimálním využití předem stanoveného objemu zdrojů dosaženo definované úrovně aktiva (Parker, 1986). Tento př́istup je nejvhodnější a nejjednodušší uvést na př́kladu grantového schématu s omezeným rozpočtem, v rámci kterého má být realizováno co nejvíce kvalitativně srovnatelných projektů. Ve světle uvedeného prríkladu je vhodné zmínit, že Kanadská kancelář auditorů (Office of the Auditor General of Canada, 1995) uvádí, že efektivnost indikuje jakým způsobem organizace využívá své či svěřené zdroje k realizaci statků či služeb.

Třetím „E“ je účinnost (effectiveness). Dle Parker (1986) lze účinnost definovat jako poměr či stupeň dosažených cílů ve vztahu k cílům stanoveným. Rozdílný pohled na účinnost ovšem existuje v rámci zapojení zdrojů do definice. Někteří autoři, jako např. Hendrych (2003), vztah zdrojů a účinnosti téměř vylučují, Glynn (1985) žádnou vazbu neuvádí a Parker (1986) uvádí vhodnost stanovení vztahu mezi vynaloženými prostředky a dosaženým stupněm účinnosti tak, aby mohlo být rozhodnuto o relevanci investovaných prostředků.

$\mathrm{V}$ př́ípadě, že tato $3 \mathrm{E}$ nejsou splněna, tzn. investice není hospodárná, efektivní a účinná, je vhodné, ba přímo nutné, využít jiné možnosti pořízení požadovaného aktiva či požadované služby či dokonce zrušení záměru jejího pořízení. Rozhodnutí o vhodnosti či nevhodnosti využití veřejně-soukromého partnerství (a tedy i o naplnění uvedených $3 \mathrm{E}$ ) by mělo být determinováo stanovenou hodnotou ukazatele VFM. Problematikou stanovení VFM v České republice se nazývá např. Ostř́žžek (2010).

Krom těchto tří hesel, která vystihují ideu NPM (a současně i VFM), je obvykle uváděno několik dalších bodů, které NPM poměrně slušně charakterizují a které vysvětlují vlastní činnosti a procesy prováděné v rámci NPM. Dle Volka a Přenosila (2005) jsou jimi:

- Zaměření se na efektivní využití zdrojů pro dosažení vysoké kvality poskytovaných služeb,

- Konkurenční prostředí mezi veřejným a soukromým sektorem při poskytování služeb,

- Tržně orientovaný přístup, nebot' občané jsou spotřebiteli/uživateli služeb,

- Vysoká míra odpovědnosti manažera veřejného sektoru.

Všechny uvedené charakteristiky velmi nahrávají využití PPP projektů při zajištění veřejných statků a služeb. Koncept NPM je logicky rozššřen především ve Velké Británii a v zemích, kde se setkáváme se systematickým využíváním partnerství veřejného a soukromého sektoru. Greve a Hodge (2007) mezi NPM a PPP nalezli souvislost, která plně podporuje předchozí tvrzení, když uvádějí, že idea PPP se stejně jako NPM rozvinula ve Velké Británii a následně rozšíŕila do dalších států, jako je Austrálie (zejména stát Victoria), Kanada a další. Tito autoři také považují PPP jako logický následek zavední NPM 
ve vyjmenovaných zemích. Dle mého názoru se v rámci NPM jedná o zásadní zlom v prosazování tržní orientace poskytování veřejných služeb.

NPM je ovšem v současné době v některých státech nahrazováno či doplňováno novým, pokročilým směrem řízení veřejné správy, jímž je tzv. NPS (New Public Service). Striktně vzato se v případě NPS nejedná o styl řízení veřejné správy, ale spíše o soubor názorů na roli veřejné správy v rámci celého systému „,vládnutí“ (governance). Hlavní rozdíl mezi NPM a NPS dle mého názoru spočívá v tom, že jeho koncept neřeší to, jak řídit a vládnout, ale jak sloužit občanům. NPS je dle Denhardtové a Denhardta (2003) výsledkem procesů a aktivit založených na teoriích občanství, komunit a občanské společnosti, organizovaného humanismu, nové veřejné správy a postmodernismu. Stejní autoři uvádí sedm hlavních charakteristik NPS:

1) Služba občanům, nikoli zákazníkům - veřejný zájem je výsledkem dialogu o společných hodnotách, nikoli agregátem individuálních zájmů. Nejedná se tedy pouze o pokrytí poptávky, ale o budování vztahu s občany.

2) Vyhledávání veřejného zájmu - v souvislosti s prvním bodem má veřejný sektor přispívat k budování kolektivního veřejného zájmu a nehledat rychlá řešení pro individuální potřeby.

3) Předřadit občanství před podnikání - veřejný zájem je více podporován veřejnými/státními zaměstnanci a občany než podnikateli orieantovanými na podnikatelské cíle/zisk.

4) Přemýšlení strategické, konání demokratické - programových veřejných potřeb může být efektivněji a odpovědněji dosaženo díky kolektivnímu úsilí a spolupráci.

5) Rozpoznání nejednoduchosti odpovědnosti - veřejní zaměstnanci by měli být více pečliví a pozorní, měli by dbát na dodržování práva, společenských hodnot, politických norem, veřejných standardů a občanských zájmů.

6) Sloužit spíše než řídit - pro státní zaměstnance je důležité, aby využívali společné hodnoty a styl vedení, který uspokojí potřeby občanů, než aby se snažili kontrolovat a řídit společnost do nových směrů.

7) Hodnotit lidi, ne pouze produktivitu - veřejné organizace a sítě, ve kterých tyto organizace pracují, dosahují úspěchu v dlouhém období v případě, kdy je jejich práce založena na spolupráci a společných hodnotách.

Tyto téměř idealistické charakteritiky NPS mají jeden společný rys, a to sice důraz na veřejný zájem a službu veřejnosti poskytovanou státními zaměstnanci. Na první pohled to sice není ideální prostř̌edí pro PPP, ovšem při bližším prozkoumání, a při určité reformulaci některých výchozích definic, které se opírají pouze o veřejný sektor, je možné nalézt uplatnění PPP i v tomto prrípadě. Jedná se např́íklad o vyhledávání veřejného zájmu, jasnou alokaci odpovědnosti, službu veřejnosti apod. Autoři, kteří se problematikou NPS zabývají, např. John Forrer z The George Washington University uvádí, že současný rozvoj NPS v USA je jednou z klíčových determinant rozvoje amerického PPP trhu.

Sumarizací výše uvedených tvrzení dojdeme k tezi, že u veřejných statků, vyjma tzv. „,core government services“, by při jejich pořizování měla být zvažována možnost vstupu komerčního sektoru, přičemž k jeho zapojení by mělo dojít pouze v případě, že se bude jednat o efektivnější způsob realizace, nežli by tomu bylo bez jeho účasti (tzn. dosažení vyšší VfM). 
V případě, že vláda uvažuje o realizaci veřejné služby či infrastruktury, má pochopitelně vícě možností, jak poptávku po těchto službách/strukturách „,pokrýt“. Mezi alternativní př́ístupy realizace veřejných služeb/infrastruktury dle Allen (1989) patř́i:

1. Smlouva o doručení služby/infrastruktury - vláda (VS obecně) může najmout privátní firmu (i neziskovou organizaci), aby zajistila část popř. všechny jí požadované veřejné služby a statky (klasické pojetí veřejných zakázek).

2. Franchises - vláda poskytne privátní firmě exkluzivní nebo neexkluzivní franchisingovou licenci. Tato firma pak provádí jí svěřejnou činnost (provozuje veřejnou službu nebo doručuje veřejný statek), přičemž poplatky od koncových uživatelů přijímá privátní firma (teoreticky by se mohlo jednat o vytvoření sítě soukromě spravovaných pracovních úřadů nebo sítě nemocnic se ,značkou státem podporované" nemocnice).

3. Granty/dotace - vláda provádí finanční nebo nefinanční (naturální) transfery privátním společnostem jako podnět $\mathrm{k}$ poskytování veřejných služeb těmito organizacemi s tím, že tyto služby už vláda neposkytuje (dotace a granty pro firmy poskytující rekvalifikační kurzy).

4. Vouchery/poukázky - vláda distribuuje vouchery/poukázky těm, kteří potřebují využívat určitý druh veřejné služby. Tito spotřebitelé dané služby mají na výběr, kterou privátní společnost (poskytovatele služby) si vyberou s tím, že platbou za tuto službu je od vlády obdržený voucher.

5. Dobrovolníci - jedinci, kteří dorovolně pracují pro veřejný sektor, a tím poskytují zdarma veřejné služby.

6. Svépomoc - vláda podněcuje skupiny jedinců, jako jsou sousedské organizace a jiné komunity, aby převzaly část zodpovědnosti za svoji skupinu/komunitu. Tím přenáší závazek poskytování veřejných služeb na tyto skupiny (může se jednat např. o úklid veřejných prostranství v komunitě).

7. Využití daňových a regulačních agentur - vláda podněcuje daňové a regulační úřady/autority tak, aby dosáhla produkce veřejných služeb privátními společnostmi, popř. aby dosáhla snížení poptávky po veřejných službách.

8. Využití poplatků s redukcí poptávky - vláda zpoplatňuje služby a statky takovým způsobem, že fiskální břemeno přenáší na uživatele infrastruktury. Platby koncových uživatelů závisí na intenzitě využívání této infrastruktury.

9. Demarketing/redukce poptávky po službě - vláda využívá takových nástrojů a marketingových technik, které snižují poptávku po dané službě či infrastruktuře.

10. Využití dočastné pomoci od privátních firem - soukromé společnosti či osoby poskytnou vládě v př́ípadě potřeby svoji pomoc (realizovatelné v době povodní firma poskytně napřr. vysoušeče či jiné vybavení).

11. Sourkomo-veřejné joint-ventures - vláda a soukromé společnosti vytvorří jednu společnost popř. se dočasně spojí za účelem rozvoje nového zásadního projektu či jeho revitalizace (v zásadě je možné pojmout jako PPP)

Řada uvedených alternativ je relevantní pouze pro menší či komunální projekty, primárně pak pro služby. Pro rozsáhlejší projekty, jakými jsou stavby a dlouhodobá správa dálnic, nemocnic, věznic či např. veřejného osvětlení, jsou ovšem, dle mého názoru, realizovatlné pouze tři uvedené scénáře - 1. smlouva o doručení (klasická veřejná zakázka), 2. franchise možnost, která v ČR prozatím nenašla uplatnění a 11 . soukromě-veřejné joint-ventures - což je možné pojmout jako schéma PPP projektu. Vyřadíme-li z výše uvedených důvodů z rozhodování o volbě vhodné formy realizace druhou jmenovanou franchízu, rozhodujeme o realizaci plánované investice bud' prostřednictvím veřejné zakázky, nebo protřednictvím veřejně-soukromého partnerství. 
Vstup soukromého partnera do aktivit veřejného sektoru, jakými zajištění veřejných služeb je, s sebou nese potenciální výhody, ale také možné problémy. Otázku výhodnosti a vhodnosti zapojení soukromého sektoru při poskytování veřejných služeb analyzoval i Allen (1989). Jako důvody pro vyšší zapojení soukromého sektoru uvedl následující teze:

Zisk zvláštních dovedností a „Zaměstnanců“ na krátký časový úsek. Patří sem naprríklad smlouvy s architekty, právníky a poradci. Tato forma spolupráce je využívána již dlouhou dobu.

Dorovnání nabídky/chybějící kapacity vlády až na úroveň poptávky. V případě, kdy vláda nechce nebo nemůže přijmout další pracovní síly nebo ze stejného důvodu nerealizuje výstavbu nových budov, je nejefektivnější využít služeb veřejného sektoru.

Redukce nákladů. Tento důvod vychází ze základní teze, že soukromý sektor hospodaří efektivněji, než sektor veřejný. Tento důvod má vyšší význam pro lokální vlády.

Zlepšení kvality služeb. V př́ípadě nutnosti může stát využít soukromý sektor ke zvýšení kvality služeb. Toto je možné jak protřednictví provedení auditu a nápravných kroků nebo prostřednictvím přímého výkonu dané služby veřejným sektorem.

Poskytnutí možnosti většího výběru koncovému spotřebiteli - občanovi. V případě, že vláda využije např. formu voucherů nebo franchíz, dochází ke střetu trhu s veřejnými statky a službami se standardními tržními silami a konkurenčním prostředím, což může sekundárně vést ke zefektivnění poskytování těchto služeb.

Ideologie. Pro určité skupiny lidí je politika minimálních aktivit státu tím rozhodujícím důvodem pro zapojení soukromého sektoru do ekonomiky.

V rámci objektivního pohledu na vstup soukromého partnera do veřejného investování - do realizace veřejných služeb a infrastruktur analyzoval tentýž autor i potenciální výhody a možné problémy.

Tabulka 1: Výhody a nevýhody zapojení soukromého partnera do veřejného investování

\begin{tabular}{|c|c|}
\hline Možné výhody & Možné problémy \\
\hline $\begin{array}{l}\text { Méně byrokracie - pravidla a regule vyskytující } \\
\text { se ve veřejném sektoru obvykle zpomalují jeho } \\
\text { činnost. Dalším problémem veřejného sektoru je } \\
\text { „mnohovrstevnost““ jeho řízení a nutnost řady } \\
\text { podpisů, razítek a schválení k provedení dílčí } \\
\text { změny. }\end{array}$ & $\begin{array}{l}\text { Možnost korupce. Je-li pro soukromý sektor } \\
\text { vidina finančních toků a výhod značná, existuje } \\
\text { nebezpečí nekalosoutěžního jednání, popř. přímo } \\
\text { korupce. Příkladů k potvrzení této teze je celá } \\
\text { řada, a proto si nevyžaduje podrobnější komentářr. } \\
\text { Zabránit těmto snahám lze pouze prostřednictvím } \\
\text { skutečně transparentních tendrů a osobní } \\
\text { zodpovědnosti zainteresovaných jedinců. }\end{array}$ \\
\hline $\begin{array}{l}\text { Konkurence - soutěžní prostředí. Vláda se } \\
\text { obvykle chová jako monopolista, což jí umožňuje } \\
\text { činit kroky, které nejsou z hlediska celkového } \\
\text { blahobytu (přebytek spotřebitele x producenta) } \\
\text { výhodné. Zvýšení konkurenceschopnosti s sebou } \\
\text { nese snížení nákladů a zkvalitnění služeb. }\end{array}$ & $\begin{array}{l}\text { Možnost snížení kvality. V případě fixních } \\
\text { plateb soukromému sektoru, popř. plateb za } \\
\text { jednotku, může existovat tlak na snížení } \\
\text { výrobních nákladů jako zdroj zvýšení zisků } \\
\text { poskytovatele. Toto snížení nákladů ovšem může } \\
\text { způsobit snížení kvality. Obranou vǔči tomuto } \\
\text { trendu jsou jasná smluvní ujednání, standardy } \\
\text { kvality a sankční aparát. }\end{array}$ \\
\hline
\end{tabular}




\begin{tabular}{|c|c|}
\hline $\begin{array}{l}\text { Nižší jednotkové náklady. Soukromé firmy se } \\
\text { častěji než veřejný sektor pohybují na více trzích, } \\
\text { diverzifikují tak portfolio svých služeb a mají } \\
\text { tudíż lepší možnosti v rozpoznání a vývoji nových } \\
\text { technologií, manažerských technik či } \\
\text { informačních systémů. Mohou také lépe využít } \\
\text { úspory z rozsahu a úspory ze sortimentu. } \\
\text { Z důvodu vyššího (platového) ohodnocení } \\
\text { zaměstnancủ také disponují zaměstnanci } \\
\text { kvalitnějšími a kvalifikovanějšími. }\end{array}$ & $\begin{array}{l}\text { Zvýšená možnost přerušení dodávek služeb. } \\
\text { Soukromý sektor je náchylnější k rozpočtovým } \\
\text { škrtům v př́ípadě, není-li daná aktivita či projekt } \\
\text { zisková či dostatečně atraktivní. Zásadní problém } \\
\text { může nastat v případě, kdy toto přerušení služby } \\
\text { vyústí v ohrožení zdravíči bezpečnosti občanů. }\end{array}$ \\
\hline & $\begin{array}{l}\text { Možné omezení přístupu ke službě pro } \\
\text { znevýhodněné, popř. postižené, klienty. } \\
\text { Soukromé společnosti se mohou snažit o vyhnutí } \\
\text { se poskytování služeb těm, kteří mohou mít } \\
\text { problémy s platbou nebo těm, jejichž participace } \\
\text { na dané službě by mohla být velmi drahá. }\end{array}$ \\
\hline
\end{tabular}

Zdroj: převzato a upraveno z Allen (1989)

Je zřejmé, že možných problémů se zapojením soukromého partnera do diskutovaných aktivit je celá řada. $Z$ tohoto důvodu jsou jedním z nejdůležtějších předpokladů úspěšného zapojení striktní a zcela jasně definovaná pravidla spolupráce, jež musí mít oporu v zákoně. V České republice jsou hlavními zákony souvisejícími s veřejným zadáváním zákon č. 137/2006 Sb. o veřejných zakázkách a zákon č. 139/2006 Sb. o koncesních smlouvách a koncesním řízení. Je zřejmé, že se v rámci smluvních vztahů a jejich kompletace využívá řada dalších zákonů, jako je např. obchodní zákoník, stavební zákon apod. Cílem této práce ovšem není legislativní analýza PPP prostředí v ČR a proto se legislativním souvislostem a právnímu prostředí nebudeme blíže věnovat.

Jak uvedený výčet možných alternativ, tak diskutované výhody a nevýhody vstupu soukromého partnera do aktivit tradičně náležejících veřejnému sektoru nás vedou ke srovnání dvou alternativ - veřejné zakázky a veřejně soukromého partnerství ${ }^{1}$.

Tabulka 2: Srovnání smluvního a partnerského vztahu

\begin{tabular}{|c|c|c|}
\hline Vlastnost & Smluvní vztah & Partnerský vztah \\
\hline Typ vztahu & Zákazník (VS) a dodavatel (SS) & Společné rozhodování \\
\hline $\begin{array}{l}\text { Rozdělení } \\
\text { zodpovědnosti }\end{array}$ & $\begin{array}{l}\text { Jasné rozdělení (ve vývoji }- \\
\text { přípravě i v realizaci) }\end{array}$ & $\begin{array}{l}\text { Společná zodpovědnost (v př́pravě a } \\
\text { často i v realizaci) }\end{array}$ \\
\hline $\begin{array}{l}\text { Specifikace problému } \\
\text { a řešení }\end{array}$ & $\begin{array}{l}\text { VS specifikuje problémy a jejich } \\
\text { řešení (tzn. požadovaný výstup) }\end{array}$ & $\begin{array}{l}\text { Obě strany se účastní identifikace } \\
\text { problému a hledání jejich řešení } \\
\text { (obdoba soutěžního dialogu) }\end{array}$ \\
\hline $\begin{array}{l}\text { Rozsah/rámec } \\
\text { projektu }\end{array}$ & 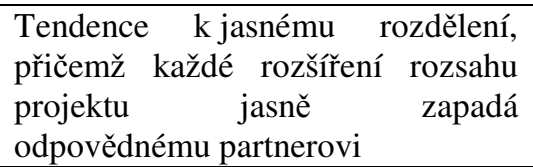 & $\begin{array}{l}\text { Snaha o hledání možností rozšíření } \\
\text { rozsahu a kompletaci jednotlivých } \\
\text { součástí projektu }\end{array}$ \\
\hline Předpoklady úspěchu & $\begin{array}{l}\text { Jasná smlouva, jasná a nesporná } \\
\text { soutěžní/smluvní pravidla a přesná } \\
\text { specifikace výstupu }\end{array}$ & $\begin{array}{l}\text { Spojení záměrů a cílů obou sektorů, } \\
\text { efektivní pravidla vytváření závazků a } \\
\text { ziskové spolupráce }\end{array}$ \\
\hline Organizační principy & $\begin{array}{l}\text { Striktní oddělení obou sektorů, } \\
\text { jasná smluvní pravidla, dodržení } \\
\text { soutěžních principů, pravidla pro } \\
\text { hodnocení výstupů }\end{array}$ & $\begin{array}{l}\text { Společná pravidla pro: rozhodování, } \\
\text { ukončení spolupráce, řešení konfliktů, } \\
\text { společnou produkci a dělení výnosů }\end{array}$ \\
\hline
\end{tabular}

${ }^{1}$ Zde je vhodné upozornit na fakt, že pojmy veřejná zakázka a veřejně soukromé partnerství chápeme v ekonomickém smyslu, nikoli ve smyslu právním (tzn. jak je daný projekt zadáván - dle kterého zákona - jde-li o veřejnou zakázku kvazikoncesi či koncesi). 


\begin{tabular}{|l|l|l|}
\hline Principy řízení & $\begin{array}{l}\text { Silně založené na principech } \\
\text { projektového } \\
\text { (specifikace cílů, organizace } \\
\text { časového plánování, }\end{array}$ & $\begin{array}{l}\text { Silně založené na principech řízení } \\
\text { procesů (hledání cílů, spojování } \\
\text { aktivit aktérů, spojování rozhodování) }\end{array}$ \\
\hline Výměna informací & $\begin{array}{l}\text { Striktně oddělená a využitá jako } \\
\text { strategický zdroj }\end{array}$ & $\begin{array}{l}\text { Nepostradatelný zdroj, který musí být } \\
\text { sdílen aktéry procesu }\end{array}$ \\
\hline $\begin{array}{l}\text { Platební/finanční } \\
\text { podmínky }\end{array}$ & $\begin{array}{l}\text { Subjekty maximalizují svůj zisk } \\
\text { (jasné oddělení finančních toků) }\end{array}$ & Subjekty maximalizují společný zisk \\
\hline Typ spolupráce & $\begin{array}{l}\text { Limitovaná a spojená především se } \\
\text { smluvním procesem. Poté se jedná } \\
\text { o monitoring a kontrolu, ne o } \\
\text { spolupráci. }\end{array}$ & $\begin{array}{l}\text { Rozsáhlá spolupráce během celého } \\
\text { procesu. Její zaměření se mění s fází } \\
\text { projektu. }\end{array}$ \\
\hline
\end{tabular}

Zdroj: Klijn, Edelenbos, Hughes (2007)

Zajímavé srovnání obou alternativ nabízí Klijn, Edelenbos a Hughes (2007), kteří veřejnou zakázku oecně považují za smluvní vztah a PPP za formu partnerství. Z právní hlediska je ovšem dělení ne smluvní vztah a partnerství nevhodné, nebot' jak veřejné zakázka, tak PPP projekt, je právně zajištěn právě prostřednictvím smlouvy.

Stejně jako u definování hlavních charakteristik NPS i zde narážíme na velmi ideální formu definovaného partnerství. Ovšem hlavní myšlenky v uvedeném výčtu vlastností partnerství je možné v rámci PPP projektů realizovat.

\section{Závěr}

Z předchozího textu vyplývá, že existují jednoznačně definovatelné vazby mezi konceptem PPP a mezi moderními pojetími organizace veřejné správy a prŕístupu k jejich řízení. Současně se jedná o způsoby řízení veřejných výdajů a možné způsoby pořízení veřejných služeb a infrastruktury s tím, že v nich můžeme vypozorovat důraz na pojetí poskytování tohoto typu statků jako služeb. Z teoretického hlediska je pak možné konstatovat, že v rámci př́ístupu New Public Managemet a zvláště pak v rámci př́istupu New Public Service, je forma veřejněsoukromých partnerství nejen přijatelná, ale přímo vhodná a vyhledávaná, a to i z důvodu dlouhodobého charakteru těchto projektů. Doporučení, která se lze na základě provedené práce formulovat, jednoznačně souvisí s pokračováním reformy veřejné správy a její modernizací tak, aby se právě ve veřejné a státní správě uplatňovaly moderní formy řízení, prostřednictvím kterých bude dosaženo vyšší efektivity vynaložených prostředkủ a uspokojení potřeb spotřebitelů (voliči). Autor tohoto příspěvku se domnívá, že zavedení a důsledná aplikace moderních forem řízení a důraz na efektivní využívání zdrojů mohou stát u akcelerace zadávání a realizace projektů formou PPP.

V rámci objektivního pohledu na vstup soukromého partnera do veřejného investování je nutné připomenout, že možných problémů se zapojením soukromého partnera do diskutovaných aktivit je celá řada (Ostř́ǐzek - 2010, Mach - 2003 či Hall - 2008). Z tohoto důvodu jsou jedním z nejdůležtějších předpokladů úspěšného zapojení soukromého sektoru striktní a zcela jasně definovaná pravidla spolupráce, jež vychází z platné legislativy, existujícího deal flow a především z uzavřené smlouvy, jejíž správná formulace je pro úspěšnost projektu nezbytná. 


\section{Literatura:}

[1] ALLEN, J.W. The Private sector in state service delivery : examples of innovative pratices. Washington, D.C. : Council of State Governments : Urban Institute Press ; Lanham, MD. Distributed in the United States and Canada by University Press of America, 1989. ISBN 0877664617

[2] BAR-EL, R. Infrastructure investment and regional underdevelopment. In Public investment and regional economic development / edited by D. Felsenstein, R. McQuaid, P. McCann a D. Shefer. Cheltenham, UK; Northampton, MA: Edward Elgar, 2001. ISBN 1840647159

[3] BUCHANAN, J. An Economic Theory of Clubs. Economica. 1965. 32, pp. 1-14.

[4] DENHARDT, J., DENHARDT, R. The new public service : serving, not steering. Armonk, N.Y.: M.E. Sharpe, c2003. ISBN 0765608456

[5] GLYNN, JOHN J. Value for money auditing in the public sector. Englewood Cliffs; London: Prentice-Hall in association with Institute of Chartered Accountants in England and Wales, c1985. ISBN 0139403477

[6] GREVE, C., HODGE, G. Public-private partnership: a comparative perspective on Victoria and Denmark. In Christensen, T., Lægreid, P. Transcending new public management: the transformation of public sector reforms. Aldershot, England; Burlington, VT: Ashgate, c2007. ISBN 9780754670711

[7] HALL, D. Public-Private Partnerships (PPPs) in the EU - a critical appraisal. 2008. PSIRU November 2008. Presented paper. Online. Dostupné z: http://www.psiru.org/reports/2008-11-PPPs-crit.doc

[8] HENDRYCH, D. Správní věda - Teorie veřejné správy. Praha: ASPI Publishing, 2003. ISBN 80-86 395-86-3

[9] HOLMAN, R. Dějiny ekonomického myšlení. C.H. Beck. Praha. 1999. ISBN 8071793809

[10] IMF. Public Investment and Fiscal Policy. 2004. International Monetary Fund - Fiscal Affairs Department and the Policy Development and Review Department Washington, D.C.

[11] KARAGIANNI, S., M. PEMPETZOGLU, STRIKOU, S. (2002) “Testing Wagner's law for the. European Union economies." The Journal of Applied Business Research. Vol.18, No 4.

[12] KLIJN, E.H., EDELENBOS, J., HUGHES, M. Public-Private Partnership: a TwoHeaded Reform. A Comparison of PPP in England and the Netherlands. In Pollitt, C., Van Thiel, S., Homburg, V. New public management in Europe: adaptation and alternatives. Basingstoke [England]; New York: Palgrave Macmillan, 2007. ISBN 0230006930

[13] MACH, P. Riskantní prodej budoucích daňových výnosů. 2003. CEP Newsletter. Centrum pro ekonomiku a politiku. Praha. Listopad/Prosinec 2003.

[14] Office of the Auditor General of Canada, 1995. Auditing of Efficiency. OAG. Canada. 1995. Online. http://www.oag-bvg.gc.ca/internet/English/meth_gde_e_20331.html\#2_1

[15] OSTŘÍŽEK, J. a kol. Public Private Partnership - příležitost a výzva. C.H. Beck. Praha. 2007. ISBN 8071797449

[16] OSTŘÍŽEK, J. Value for Money jako nástroj hodnocení PPP projektů-Mezinárodní srovnání a návrh úpravy metodiky hodnocení projektů v České republice. Mendelova univerzita v Brně. 2010. 220s. Disertační práce.

[17] OSTŘIZŽEK, J., KOUBA, L. Teoretické a praktické aspekty realizace PPP projektio. 1. vyd. Brno: Mendelova univerzita v Brně, 2011. 90 s. FOLIA IV, 6. ISBN 978-807375-538-6. 
[18] PARKER, LEE D. Value-for-money auditing: conceptual, development and operational issues. Caulfield, Vic.: Australian Accounting Research Foundation, 1986. ISBN 0909744335

[19] PEREÉ, E., VÄLILÄ, T. A primer on Public investment in Europe. Public investment and public-private partnerships : addressing infrastructure challenges and managing fiscal risks / edited by Gerd Schwartz, Ana Corbacho, and Katja Funke. Basingstoke [England]; New York: Palgrave Macmillan/International Monetary Fund, 2008. ISBN 0230201334

[20] PERSKY, J. FELSENSTEIN, D. A Job Chains model for assessing employment creation in local labour markets. In Public investment and regional economic development / edited by D. Felsenstein, R. McQuaid, P. McCann a D. Shefer. Cheltenham, UK. Northampton, MA: Edward Elgar, 2001. ISBN 1840647159

[21] SHELDON, D.R., McNAMARA E.F. Value-for-money auditing in the public sector : strategies for accountability in the 1990s. Altamonte Springs, Fla. : Institute of Internal Auditors Research Foundation, c1991. ISBN 0894132474

[22] TOPINKOVÁ, P. Ověření Wagnerova zákona -- aplikace pro Českou republiku. 2010. Diplomová práce. Mendelova univerzita. Brno.

[23] VOLEK, P., PŘENOSIL, J. Veřejná správa. 1. vyd. Brno: Mendelova zemědělská a lesnická univerzita, 2005. 161 s. ISBN 80-7157-847-9

[24] WU, J-W. OPTIMAL REGIONAL GROWTH AND PUBLIC INVESTMENT MODELS: THEORY AND APPLICATION TO THE EFFICIENCY-EQUITY ISSUE IN TAIWAN. University of Pennsylvania, 1987, 198 pages; Disertation thesis. AAT 8714156

Klasifikace JEL: H83, H42

\section{Ing. Jan Ostř́ížek, Ph.D.}

Ústav financí

Provozně ekonomická fakulta

MENDELU v Brně

Zemědělská 1, 613 00, Brno

jan.ostrizek@mendelu.cz 